\title{
Correspondence
}

\section{Griseofulvin therapy in Herpes progenitalis (A double-blind controlled trial)}

\author{
TO THE EDITOR British fournal of Venereal Diseases
}

SIR-With the possible exception of idoxuridine no satisfactory therapeutic agent is known for the treatment of Herpes progenitalis or labialis. I should like to report my preliminary results with griseofulvin, a well-known antifungal antibiotic.

38 patients, comprising 33 with Herpes progenitalis and five with Herpes labialis, were admitted to the trial which lasted from August, 1972, to May, 1973. Diagnosis was based on the history of prodromal symptoms such as a burning sensation and pain, and the presence of typical grouped vesicular lesions. It was reinforced by a history of recurrent lesions. In a few cases the diagnosis was supplemented by demonstration of balloon cells on cytological examination.

Each patient was given either four $500 \mathrm{mg}$. tablets of griseofulvin, or a placebo, by mouth in two divided doses daily for 14 days. The allocation to each group was by random fashion and the contents of the tablets were known neither to the investigator nor to the patients.

Each patient was asked to report for follow-up after 4,8 , and 15 days, or at any time in the event of the reappearance of similar lesions. Improvement was assessed by noting alleviation of symptoms and by objective observation of the regression of vesicular and erosive lesions. Recurrences during the observation period were recorded.

Nineteen patients received griseofulvin and nineteen placebo. There were 35 males and three females. Apart from three children, the patients' ages ranged from 17 to

Griseofulvin-F.P. was provided by Glaxo Laboratories (India) Ltd.
48 years in both groups. The two groups were comparable regarding the duration and severity of the lesions.

Of the nineteen patients who received griseofulvin, 14, including three with Herpes labialis, showed complete remission (Table). In seven cases recovery was noted after four days, in six after 8 days, and in one after 15 days. There was diminution of symptoms such as burning, pain, and itching within 24 hours of starting therapy. There was only one patient who did not show any improvement and four dropped out of the trial. Recurrences were recorded in only two patients.

In the nineteen patients receiving placebo, eight patients, including the two with Herpes labialis, had a complete remission. This was noted after 4 days in one, after 8 days in five, and after 15 days in two. Seven showed no response. There were four who defaulted and five recurrences (Table).

The results obtained are statistically significant at the 2 per cent. level ( $\chi^{2}=6 \cdot 14$ for $1 \mathrm{df} ; \mathrm{P}<0.02$ ).

One can only conjecture as to the mode of action of griseofulvin in this disease. The drug can affect nucleic acid synthesis and thus possibly inhibit the multiplication of the virus; or it may act through its well-known antiinflammatory action. Further trials in other centres are called for.

$$
\text { Yours faithfully, }
$$

V. N. SEHGAL

Department of Venereology and Dermatology,

GoA Medical College, Panaji 403001, GoA (INDIA)

August 6, 1973

TABLE Response to treatment by 38 patients ${ }^{\star}$

\begin{tabular}{|c|c|c|c|c|c|c|}
\hline \multirow{3}{*}{ Follow-up (days) } & \multicolumn{6}{|l|}{ Results } \\
\hline & \multicolumn{2}{|c|}{ Complete recovery } & \multicolumn{2}{|l|}{ No recovery } & \multicolumn{2}{|l|}{ Recurrence } \\
\hline & Griseofulvin & Placebo & Griseofulvin & Placebo & Griseofulvin & Placebo \\
\hline $\begin{array}{r}4 \\
8 \\
15\end{array}$ & $\begin{array}{l}7 \\
6 \\
1\end{array}$ & $\begin{array}{l}1 \\
5 \\
2\end{array}$ & $\frac{-}{1}$ & $\overline{7}$ & 2 & 5 \\
\hline Total & 14 & 8 & 1 & 7 & 2 & 5 \\
\hline
\end{tabular}

^Four patients in each group defaulted 